\title{
Social Discourse, Comfort Zones and the Globalising World: South African Indian Emigrant and Resident Doctors on the Need to Migrate
}

DOI: $10.11567 /$ met.30.2.6

UDK: $316.4: 616-051(684=214)$

$314.74: 616-051(684=214)$

Izvorni znanstveni rad

Primljeno: 2.9.2014.

Prihvaćeno: 3.11.2014.

\section{Anand Singh}

Department of Anthropology, University of KwaZulu-Natal, Durban

singhan@ukzn.ac.za

\begin{abstract}
SUMMARY
This paper is about conversations and opinions of Indian medical personnel who are working outside and inside South Africa. It covers the views of two groups: of medical general practitioners and medical specialists. The first group, with whom interviews were done as casual conversations individually and collectively, were employed outside the country. They were in the age group beyond 60 years of age, while the group inside the country were below the age of 40 years and were represented by the individual interviews with their close relatives. While the older group saw themselves as being bestowed with the twin advantages of experience and wisdom, the younger often articulated feelings that were in juxtaposition to one another. They expressed their appreciation for the comfort zones in which they were established but felt at odds with themselves when they compared their situations with their counterparts working in other countries, especially in the Middle East and the developed English speaking countries (especially the "big five": USA, Canada, UK, Australia and New Zealand). However settled, and no matter how they felt about themselves, the conversations with the members from each group were fraught on both sides with degrees of ambivalence, regret, success and confidence about their futures.
\end{abstract}

KEY WORDS: professional migrants, medical practicioners, Indian, South African, globalisation

\section{INTRODUCTION}

Recent research about the migration of doctors and other professionals from South Africa to countries with assumedly more conducive working conditions and social environments, have focussed only upon Whites (Van 
Rooyen, 2000; Bezuidenhout et al., 2009; Arnold, 2011). Across all of these references, a common denominator that has emerged is the general dissatisfaction with living in South Africa. Two of the titles bear dramatic representations of Whites wanting to leave the country such as van Rooyen's (2000) The New Great Trek: the story of South Africa's White exodus, and Arnold's title: A unique migration: South African doctors Fleeing to Australia. The words "exodus" and "fleeing" are deliberate and they are intended to convey a sense of powerlessness against those wanting to relocate. Bezuidenhout et al. (2009: 211) referred to a 2004 newspaper report which predicted that by 2006, 40 percent of South Africa's physicians would emigrate to work in other countries. Their assessment was accurate in the reference to a study conducted in 1975 to look into the whereabouts of the University of Witwatersrand medical graduates from 1925 to 1972. The finding was prophetic in that while 83.6 per cent of those graduates practiced medicine in South Africa, by 1998 a follow-up investigation of those who graduated since 1975 found that they were located abroad, especially in the USA and the Commonwealth countries, such as the United Kingdom, Canada, Australia and New Zealand. The findings of the surveys and the personalised interviews by van Rooyen (2000) and Arnold (2011) demonstrated the weight of the push over the pull factors. Push factors centred on deteriorating working conditions in hospitals, their poor management, and upsurges in community violence, through house breaking, hijackings and murders. These conditions made the relative political and economic stability in other developed countries more appealing

While other minority communities such as Coloureds and Indians have produced numerous doctors as well from their ranks, no attention has been given to them in these surveys. This paper draws from information gleaned mainly from Indian doctors who have become ex-South Africans, working in the United States. They trained and worked in South Africa but remained sceptical about the future stability of the country. While South Africa is experiencing a perennial brain drain, it is not alone among the developing countries to be losing doctors at such a high rate. As developed countries are feeling the pinch of a prolonged global economic slowdown, they continue to cut back upon state expenditure, including the training of medical personnel, which is generally high everywhere in the world. But they are effectively using their conducive environmental conditions as persuasive forces in attracting doctors from developing countries in order to save on the enormity of the costs in producing doctors. Hagopian et al. (2004) cited the World Health Organisation's (WHO), attempts to study information 
in African countries' health systems and workforce data, to gauge the effects of physician migration on health care. The records in most countries on the continent were extremely weak, and in some instances they did not exist at all. Such paucity of information makes it difficult to understand the impact of migration on healthcare. Although 47 nations make up subSaharan Africa, there are only 87 medical schools; 11 countries do not have medical schools at all, and 24 have only one each (Hagopian et al., 2004). The comparative statistics, however, that Hagopian et al. (2004) cite provide an illuminating insight into the enormous difference between developed and developing nations' ratios between doctors and the population. SubSaharan Africa has a population of around 660 million people with a ratio of fewer than 13 physicians (doctors) per 100,000 people, or a total of 82,949 doctors across the sub-continent. In contrast, the UK has 164 physicians per 100,000 population and the USA has over 279 physicians per 100,000 people (or almost 800,000 doctors for a population of 284 million people).

Such discrepancies in health care can have the power to create significant socio-political unrest in countries, as can be seen in the Ebola affected countries such as Liberia, Sierra Leone and Guinea. The presence of doctors is a life-giving hope to people, and their absence can spell the opposite if people are in desperate need of medical attention. Fatal attacks against aid workers in September 2014 in Liberia are an indication of how people can respond in such situations. What is of significance here is the power of both the individual doctor and doctors collectively, either as state employees or as self-employed practitioners. The power of the doctor in this sense is unlike the political power that is centralised and concentrated among a collective that becomes visible through enactment and implementation of policies. Instead, it is of a diffuse type that can either enrich a state and its service delivery plans, or create political and economic havoc through sheer absence. The latter appears to be the case in contemporary South Africa as more doctors (general practitioners and specialists) continue to migrate. As the rate of relocation continues to exacerbate, it raises more questions about why a country that was once an attraction to both local and international medical experts is swiftly turning into a non-attraction. The significance of the flight of medical professionals is an implicit demonstration of something remiss within the post-apartheid state. The objective of this paper is to highlight the issues that are making South Africa a non-attraction and to provide a perspective from medical personnel who are not "White". Most literature on this subject have focussed particularly on the relocation of White medical professionals from South Africa to other countries (see for 
instance Van Rooyen, 2000; Van der Vyver and de Villiers, 2000), ignoring for instance the impact of post-apartheid transformation on people, such as people of Indian origin.

The structure of this paper is as follows: it begins with a discussion of the migration of the highly skilled in the medical profession from South Africa, which South Africa could ill afford to lose, linking it to the loss of professionals in Africa. The author then focuses on providing a background to the argument by highlighting some issues of concern in South Africa, related to the migration of professionals and the theoretical framing for the paper. This is followed by a presentation and discussion of the findings. The paper concludes with some key insights.

\section{CONTEXTUALISING ISSUES OF SOCIO-POLITICAL CONCERN IN SOUTH AFRICA}

In the process of collating information for this paper, part of the planning for its write-up was to draw from the print media, especially daily and weekend newspapers (and not tabloids) on the factors that influence young doctors' inclination to migrate. There is an inextricable link between what the print media conveys to the public in their daily life and what they themselves experience. Contemporary social life in South Africa is shaped and determined by perceptions of lurking criminals, an ineffective police force and a lack of political will to confront crime with the determination that it requires. Social gatherings therefore abound with conversations around these issues, because crime and criminality have become all pervasive in the course of political transformation in post-apartheid South Africa.

One of the reasons for drawing from the print media was to complement information that was gathered through personal conversations and interviews, as well as overhearing in social gatherings what people preferred to talk about and in what tones they spoke. All of the interviews were preceded by casual conversations that took place in small groups of three to five people and with bigger groups of more than five. People who made significant statements with strong views about the current socio-political situation in South Africa were approached for more individualised interaction. While there was care to ensure that no leading statements were made, they were prompted both within groups and in one-on-one interactions to elaborate on how they felt about political change in South Africa, how they thought it impacted upon social life and what they thought about the future for medical practitioners in the country. The social gatherings went on for 
between 2 and 4 hours and interviews went on for between 1 and 2 hours. Information from 20 medical practitioners in formal individual and group interviews is used in this paper, over and above the social gathering of 22 people that is written about here. ${ }^{1}$

Most of what was written down as field notes, especially in overhearing what was spoken, falls squarely within the ambit of anecdotal evidence. But when such evidence resonates with media reports and with published research material (Van Rooyen, 2000; Van der Vyver and de Villiers, 2000), it can serve as legitimate complementary material in either theorising or as supportive data to justifiable ethnographic evidence. But none of these three publications went beyond either inclinations towards or actual movements to other countries. The absence of articulation between their field data and theory has limited their publications to mere descriptive studies. However, the intention to seek out archival or recent material from the print media terminated right at the time when the first lines for this paper were to be penned down. Information was to be sought on factors that contributed towards the migration of the highly skilled from South Africa, especially medical personnel. The front page lead articles of two consecutive evening newspapers, and one morning newspaper obviated the need for a wider search for material. Each of the captions and the stories that followed had significance as to what is unearthed in the material below. On Tuesday, 26 August 2014, the Daily News lead article was: "Doctors blame cadres: Jobs-for-pals in public sector drives them out" (Ndaliso, 2014)²; on Wednesday, 27 August 2014, Mercury's lead article read: "Waste Pours into Midmar Dam: Pollution threat to tap water" (Carnie, 2014); and on the same evening the Daily News caption read: "SA loses R8.5bn to car theft: Durban hijackers strip bakkie while driving" (Rondganger and Ndaliso, 2014).

It is in at least one of two ways in that these captions may be read, namely the clinical way or the broader contextual way - but relative to the political position one takes on such issues. A clinical assessment of each of the captions is likely to avoid any imputation of who is responsible for the situation and how, as well as why it got to where it is. While the intention in such instances is to steer clear of controversy and to assume an apolitical position, it is hardly likely to go unchallenged because the very notion of being "apolitical" may easily be construed as political anyway. The broader contextual

At least 20 people were spoken to during and after the respective local municipality election, including the Indian candidate who cried foul during the process of voting. The interviews then were actually for another project, but are of relevance to this paper, too.

2 See also The International Mobility of Health Professionals..., 2004. 
arguments may appear on either side of the political divide that is widely prevalent in South Africa, with one side blaming apartheid and its unfolding effects, and the other blaming the current democratic government, its inexperience, inefficiency and corrupt methods of governance. Corruption has become a persistent problem of transformation in post-apartheid South Africa, especially with government officials and their cronies appearing literally on a daily basis in the media about such charges. Much of the corruption is about engaging in state tender processes, and such people have earned the euphemism of "tenderpreneurs". Wikipedia has now opened a cite to report on such matters because of the extensiveness of the problem of state corruption $^{3}$ (see also Hyslop, 2005, and Kalombo, 2005, among a range of others).

What people read into the contemporary dynamics of South Africa's civil society feeds into their social discourse, the comfort zones that they have come to occupy and their perceptions about a globalising world. Each of these concepts would be better served in this paper if appropriate definitions are ascribed to them. Social discourse has a fair measure of meaning and history attributed to it. Foucault's version of the concept has been widely referenced and often used in diverse ways as a yardstick to explain its connotations to varying situations. Numerous writers have sought to work on Foucault's theory of social discourse, because they saw in him a level of authority that few could articulate with such vision and insight. Power is more diffuse than a simplistically concentrated and coercive force. It constitutes agents across space and time that may not act as a force governed by a centralised authority (see also Gaventa, 2003). To Foucault, discourses are more than mere ways of thinking and producing meaning, and power is not always concentrated in that it is more diffuse than people tend to view it. They constitute the "nature" of the body, unconscious and conscious mind and emotional life of the subjects they seek to govern (Weedon, 1987: 108). Power circulates "in the social field and can attach to strategies of domination as well as those of resistance" (Diamond and Quinby, 1988: 185). In South Africa, like any other country, discourse by the state is almost always couched in terms of acting for the higher good of the people, a subtlety imbued with intentions and strategies to dominate. Resistance to this unfolds in numerous ways, from violent crime to finding comfort in talking about the negativities of transformation. Another reference to Foucault's understanding of "discourse" is captured in a similar but more assertive

http://en.wikipedia.org/wiki/Corruption_in_South_Africa. 
context (Gaventa, 2003; Foucault: power is everywhere): a form at whatever chance can be grasped, or simply leaving the country. But the migration by doctors, too, is a form of resistance albeit a symbolic and impersonal form of communication against the perceived socio-political malaise of a political economy. In Gaventa's (2003) terms it is a way of doctors acting as agents and their way of producing meaning and power to the services that they render (see also Foucault: power is everywhere).

Comfort zones are often reference to power and privileges that insulate and protect people against the harsh realities outside of their boundaries. Comfort zones are an integral part of people's aspirations, dreams and selffulfilling prophecies. When people want to change, it is often because they want to extricate themselves from their contemporary comfort zones. They would first have to disconnect from their current comfort zone to justify relocation to another. Hence a comfort zone can serve as an icebreaker to prevalent privileges that are seen to be beneficial but equally stagnant and retrogressive, because it generates complacency. It is in this kind of conceptual nuances that highly skilled medical personnel tend to find themselves. In South Africa, like most other countries in the world, highly qualified medical practitioners are an esteemed segment of society. They are high earners and are generally upper-middle class, well respected, and tend to be aloof from the rest of the society. But highly qualified medical personnel are among the most sought after in a world where the scarcity of such individuals looms large. Hence, a comfort zone provides them with privileges that are a source of envy to others but which is constrictive to the holistic growth and development of society across class, race and ethnic spectrums, privileges that are insufficient to their highly conscientised states of mind. Such comfort zones are perceived as inadequate and a threat to long term peace and stability, because the lack of social service provision is a poor reflection on political leadership. The consequences to this can be severe and can impact negatively on economic and political stability, as again in the prevalence of Ebola in Sierra Leone and Liberia has shown.

Globalisation has become a source of comfort as well as a solution for those whose rare skills provide them with the privilege to trade their expertise across regional and international boundaries. Over the last few decades, globalisation has come to represent a convergence of common economic practices, social values and political ambitions, but all in emulation of the "progressive West". The North America, Australia, New Zealand and European Union countries are seen as countries with levels of success that the entire world should aspire towards. But Middle Eastern countries like 
Saudi Arabia and the United Arab Emirates (UAE) also represent levels of stability and hope as tax free havens for high-end earners such as highly skilled medical personnel. Each of these countries is a potential destination for those who want to disconnect from their current comfort zones in South Africa. Their aims are to relocate to stable and better managed environments where there is a perceived sense of greater respect for human life and personal property. Against the background of comfort zones and globalisation, there is a distinct interconnection between aspects that are articulated in respect of each of them, creating platforms for a justification to leave South Africa for more perceptually attractive social and working environments.

\section{STRATEGIES OF DOMINATION AND RESISTANCE: CONTEXTUALISING THE MIGRATION OF THE HIGHLY SKILLED}

The migration of highly skilled workers has become characteristic of a movement from developing countries to developed countries. When highly skilled workers are defined as people with generally higher levels of consciousness imputed to them by virtue of their rare qualifications and consequential mature vision of civil society, highly paid, in great demand and costly to the state to train and sustain, they are taken as a cut above the rest of society. Medical expertise spans across numerous fields of specialisation, including trades, commerce, information technology, engineering, medicine and auxiliary medical services. Developing countries have invested enormously in building such specialised capacity with the intention of breaking their dependence on developed countries. However, not all of the developing countries are able to offer such skilled workers the comforts and conveniences that are prevalent in the developed countries. Lagging infrastructural deficiencies, as well as safety and security are some of the key issues that make the difference to people who offer services in big demand, who earn well and who want to be part of an environment that is conducive to their statuses. As demands for such services grow, the prices that countries are willing to pay for them tend to grow. And as developing countries become increasingly mired and polarised through failures in service delivery, the lure of political and economic stability in developing countries becomes an increasingly compelling option. Highly skilled workers add more to their wish lists as situations in their own countries continue to manifest negativities that show up systemic failures as unending problems. Their 
quest for amiable working and living environments become burdensome when viewed as the inability or lack of government will to transform their environments in ways that demonstrate promises of prosperity and stability in the longer run. When anxieties about their children's education and future prospects become issues of concern, the search for alternative answers become ever more needful. It is against these kinds of backgrounds that developed countries continue to "poach" highly skilled workers from the developing countries. African governments have voiced their objections on numerous occasions to the widespread migration of their physicians to the rich countries. Hagopian et al. (2004: 1) have placed on record a view of the South African government: "In 1996, South Africa's then Deputy President Thabo Mbeki implored the World Health Assembly to take measures to stop migration of physicians from poor countries to rich ones. In 1995, South Africa itself banned the recruitment of doctors from other Organisation of African Unity countries" (see also The International Mobility of Health Professionals..., 2004).

In South Africa, the state found it imperative to have to keep new medical graduates bound to the country for a few years longer because of the investments that have made in their education. Since 2005, the one year internship was extended to two years and to another year of Community Service. Doctors are discouraged by the state, but not in any formal constrictive way, from migrating to another country soon after their compulsory 3-year post-degree training is over. The Departments of Health at national and provincial levels are constantly engaged in assessments for medical student training as well as their retention in the public service to ensure sustainable health care within the country, especially in the under-provisioned rural areas, where half of the country's population of 50 million resides, but only 3\% of the annual graduates of 1200 appear willing to work there (Hartigh, 2012; Robinson, 2014). South Africa's eight medical schools combined capacity for first year intakes are a maximum of 2000 per annum, of which only an average of 1200 graduate every year. The differences in the conditions of infrastructural developments between the rural and the urban areas are significant. Perceptions abound about the widespread prevalence of HIV/AIDS in the rural areas and the dangers of treating so many at once in under-equipped clinics and hospitals, exacerbated by poor road and environmental conditions there. ${ }^{4}$ Yet there are impressive infrastructural advancements and economic opportunities in the urban centres that serve as

Information from doctors serving their internships in rural areas. 
beacons of hope to local residents, the rest of Africa, and also to other developing nations. The country's mix of first world facilities, an impressive national road system and well established middle and upper classes living in aesthetically pleasing suburban areas, are reasons enough to make the more privileged sectors of the nation live with a sense of hope and positivity about the future. Private and semi-private schools complement state provisioned schools, and a network of tertiary institutions throughout the country provides continuity for those wishing to advance their qualifications. South Africa's tertiary institutions now serve the interests of numerous students from other parts of the continent as well. A fair degree of encouragement in the future of South Africa was initially drawn from the at least three aspects viz. the peaceful transition to democracy through the first democratically held elections in April 1994; the success in the Truth and Reconciliation Commission (TRC) exposing apartheid's atrocities and bringing to rest the urge of the South African public to know the truth about numerous incidents that could otherwise have had the capacity to create some measure of instability; and the charismatic leadership of the late President Nelson Mandela and his road shows in assuring people of the African National Congress's commitment to reconciliation.

However, despite the positives that have marked South Africa's smooth transition to democracy, there is a fair amount of uneasiness among minorities about future prospects in the country. The South African Institute of Race Relations (SAIRR) has reported that the state has stopped collecting data on emigration since 2002 and that people no longer have to cite reasons for leaving the country. Interestingly, both SAIRR and Statistics South Africa report only about Whites as a minority and the number that emigrate annually (around 55,000 per annum). However, SAIRR CEO, Frans Cronje argued that people should not get "too caught up in the question of race." Although to him "emigration goes to the heart of failings in South Africa's society", with affirmative action and crime being the two major push factors (Smith, 2009). Despite Cronje's efforts in trying to encourage people to avoid getting caught in the question of race, his organisation still restricts its minority reports to Whites, with minimal emphasis on issues affecting Coloureds and Indians, including their emigration. Affirmative action, crime, political corruption and emigration should be just as important to Indians as they are to Whites and Coloureds. While such issues are important to Africans, too, there is hardly ever talk about emigration of African professionals to overseas countries, especially since affirmative action encourages them to exploit the opportunities that prevail for them in South Africa. Sta- 
tistics around violent crime, alleged rigged local election results, poor if not corrupt management of state resources, and affirmative action provide an indication of why such levels of unease have become so prevalent (Hyslop, 2005; Ndaliso, 2014). The media abounds on a daily basis with reports of violent crime, and people continue to make this a major topic during periods of socialisation. Local election results have been brought under the spotlight as well, when squatters from informal settlements have taken a lead in representing the interests of established suburbs in areas inhabited by mainly people of Indian origin. One of the main gripes about this aspect is that squatters, who are usually African, occupy land through invasion, and tend to outnumber the residents, thereby outvoting them for representation in the local municipality. Residents (Indian), however, cry foul about their circumstances because as taxpaying citizens they have all but lost their voice in political representation against their African counterparts in the Ethekwini Municipality. The last local elections on 18 May 2011 had allegedly become a farce among people in numerous areas where squatters reside in areas dominated by people previously classified as African. In a middle to upper class suburb dominated by people of Indian origin - Reservoir Hills, interviews with residents abounded with stories about misrepresentation and falsified voters during the local elections. The city of Durban's major daily newspapers such as The Mercury and Daily News, and the Sunday Tribune carried such stories. For example, from the week starting 19 May 2011, an independent candidate (an Indian) took the issue to the Independent Electoral Commission. Reports of the ruling party, African National Congress $(\mathrm{ANC})^{5}$ members bussing in people who were not members of the vote base in the suburb, were widely discussed. Letters of protest were sent to the print media and personal representation was made by a local organising committee for a popular resident (an Indian) who stood as a candidate. There was alleged proof that early counts had reflected that he was winning the election. This brought about a swift response among ANC cadres who arranged for more voters from neighbouring squatter camps and from the residences attached to two tertiary institutions in the city. The allegation was that regular protocol did not matter any longer, especially with respect to ensuring that people who arrived to vote were registered in the constituency. As long as a form of identity was produced people were free to vote. However, there was no countercheck to verify authenticity, nor was there any control that individuals did not vote twice. The day was

The ANC is a non-racial party but is majority African in its membership. 
marred by a high level of aggression against those who dared to speak out at the perceived unfairness or who threatened to bring this up as electoral fraud. ${ }^{6}$ It did not deter those who threatened to take action, but neither did it make much a difference to the Independent Electoral Commission (IEC) who were seen by the Indian voting public as ANC operatives. ${ }^{7}$ One of the media reports briefly covered the story in a single paragraph:

The only anomaly is Durban's Ward 23, Reservoir Hills. Predominantly Indian and always ANC-run, this is the first time that a black candidate had been fielded and won. However, Themba Solomon's appointment was halted by an independent (Indian) candidate claiming that there were irregularities in the vote counting. Change can be a bitter pill. (Pillay, 2011)

It was interesting that Pillay did not seek to elaborate on the veracity of the Indian candidate's claims. In more than 20 personal conversations with Reservoir Hills residents in 2011 immediately after the election, every respondent bemoaned the fact that squatters had the right to vote but did not contribute to the municipality's coffers in the form of rates (land taxes). One of the respondents emotively spoke of the situation:

They aggressively used their African majority position to vote in an African candidate, but our candidate was hugely popular among the rate-paying residents. He was successful, as head of the Community Policing Forum, he was more active than the police in arresting and exposing criminals in the area. But above all, he was not a ruling party candidate and he had refused to stand as one during the election, preferring to remain as an independent candidate. ${ }^{8}$

Herein lay a reverse type of domination in South Africa. While Whites dominated during the era of apartheid from spaces of generally greater privileges than other classified groups (Coloureds, Africans and Indians), such as qualitatively better living areas, Africans are dominating in greater numbers through squatter camps in the midst of middle class residential areas that are almost exclusively Indian occupied. However democratic South Africa may claim to be, this locality provides the kind of "evidence" that feeds into professionals reasons for wanting to emigrate

6 Interview with Ish Pralad (Chairman of the Reservoir Hills Community Policing Forum), 29 September 2014.

7 Although the IEC is supposedly independent, Indian voters from Reservoir Hills stated that when their grievance was lodged with the IEC, the latter waited until the result was announced and then dismissed it allegedly stating: "We cannot help you with this claim of vote rigging".

8 Conversation with Ish Pralad, 10 June 2011. 


\section{An anatomy of a social gathering with three medical specialists working overseas}

Roger Keesing's definition of a "social group" is a short but precise one with significant depth and flexibility to it: "A social group is a collectivity of individuals who recurrently interact in a set of connected identity relationships" (Keesing, 1981: 74). When applied to people of a common ethnic background and of the same generation, the connected identity relationships must incorporate issues of domestic backgrounds, socialisation processes and cuisine. It is the commonalities that emerge from these experiences that people continue to socialise, develop mutually beneficial relationships, and make decisions with a view to either remain the way they are or to change from what and where they are. It is in the casualness of social gatherings that people tend to talk in uninhibited and revealing ways. And it is in the gathering itself, in terms of who is present and invited, what might be spoken about and what might be shared through hospitalities, that connected identity relationships emerge.

On 25 February 2012, several South African born medical specialists, Indian background, gathered at a house in Reservoir Hills, Durban, for a social gathering. Twenty-two people (12 women and 10 men) including the hosts were present. Among them were several other friends and relatives with who they had schooled and spent much of their childhood and adolescent years together. Most among the group were seeing each other after many years and had included friends who had established themselves as artisans, in business and as educators. They nostalgically recalled several issues that were crucial to their early lives. At least four aspects dominated the early part of the meeting with excitement and laughter that was typical of a joyous meeting of old friends viz. the names that they used to call each other, the mischievous deeds of their younger days, the types of cuisine that were prominent then, and the work and studies that they pursued. As each had the opportunity to talk one-on-one or in smaller groups, they recollected their individual trajectories from where they began after completion of schooling and their paths towards how they got to be where they were in February 2012. While some unreachable friends were spoken or queried about, others who passed away were also remembered. Most of the gathering was made up of individuals who were teetotallers, making alcohol irrelevant to their meeting.

Among the migrant doctors, who were all resident in the United States at that time, each of the early snacks were a nostalgic reminder of what their 
mothers or extended family members used to make. But sadly for them, neither the ingredients nor the inclination by their spouses to prepare such ethnic snacks was a priority any longer. Adaptation to the new found situations nurtured them into different types of eating habits and domestic responsibilities. The envy of having many of the old networks and family members close-by and the easy availability of "Indian spices" brought about a fondness that they clearly had for Durban as their natal area. In the developed western economies the availability of relatively cheap domestic assistance is non-existent. This facility still prevails in Durban and was noted by some of the guests who still reside in South Africa as one of the reasons that their spouses refused to migrate. Household chores and domestic labour are still viewed as a woman's responsibility by women themselves, despite their attainments as career women. There was no disagreement among several of them when one woman commented in jest but with an equal measure of seriousness: "If we leave cleanliness of the house to men, we will have to change the meaning of the word! [...] You, 'Siv [...]' can manage your home in LA because of your domestication. And you are lucky enough to have left here a long time ago when your money could be converted meaningfully $[\ldots]$. We as career women will not make it there because we are too spoilt in South Africa $[\ldots]$ with our maids and our mothers $[\ldots]^{\prime \prime}$.

Each snack not only conjured up different memories and associations with known people, but also refered to the changing textures in the products that go into making them. Commercialisation of many of the products was viewed as ruthless drives to maximise profits out of adding the cheapest if not harmful preservatives in their processing. The significance of these comments lay in the memory of many of the fruit and vegetables being grown in the 1950s and 1960s without artificial fertilizer and the value and tastes that such organically grown products bring to the palate. It was the build up to the main meal that built up anticipation and expectations. There was no emphasis on any preparation that was of an affluent taste. Among Durban's wealthy Indians, especially of Hindu or Muslim background, non-vegetarian menus with prawns, lobsters and high quality lamb are what dominate the menu. When eminent guests are invited to homes, these are the types of foods, together with the finest cutlery, that are served to ensure that statuses and images are emphasised. But in this gathering it was not just expectation but hope among the doctors that almost forgotten delicacies were served. What used to be affordable working class meals in the decades of the 1950s and 1960s had now become exotic tastes that are unattainable, not just in developed countries, but in upwardly mobile In- 
dian homes, too. One of the vociferous doctors joking exclaimed: "I made it clear that I'm only coming for dinner if I get my tripe and trotters curries!" Another retorted: "You are damn lucky it is still available here. In Australia when ' $\mathrm{L}[\ldots]$ ' went to a supermarket and asked for sheep trotters they sent him to the pet's section [...] because there they only feed it to the dogs!" The comments around the main meal kept on drawing comparisons to their childhood days in Durban with the American practice of take-outs, conditioned by busy working lives and minimal home-cooking. The practice of take-outs in Durban is limited with a greater reliance of home cooked meals, periodically with the exotic delicacies that the ex-South African guests had craved so much. Home cooked meals are still possible in middle to upper class homes in Durban, even with busy working couples because of the proximity of extended family members. Domestic help is widely sought, especially from mothers/mothers-in-law for two major functions in upwardly mobile homes viz. caring for infant and school going children, and preparation of meals. While the variety of food, especially Asian and Italian, in big American cities tend to provide a range that allows people to remain unstuck to limited choices, what they have become used to in Durban, still has an appeal. But the chances of them acquiring items such as sheep tripe and trotters are rare. Ethnic food is a crucial factor in identity building. It has the tendency to draw people of a common background together and bring them to socialise around it as a mechanism of social bonding. Savouring it becomes even more convincing when what was once a regular meal has turned into something exotic, because migrating to another country makes availability of such food inaccessible.

While conversation during the meal itself was light, the more serious discussion about the realpolitik in South Africa began after it. There was a visible shift away from the smaller scattered groups to a group gathering in the garage of the hosts, which brought out more current topical issues about life in South Africa. From light-hearted comments about being carjacked or house-robbed, the conversation about transformation in South Africa from apartheid to "democracy" began taking on more serious tones. It was a story from one of the guests who was followed from the bank after withdrawing cash to pay his employees that led to more disturbing stories about friends and family becoming victims of the endemic problems of theft, violent hold-ups, corruption from the highest to the lowest levels of government, and affirmative action. In a deep and intense conversation that spanned over at least two hours, the only positives that were spoken about were the warm and generally sunny climate in Durban. None of the 
migrants had the inclination to return and contribute towards development of the post-apartheid state, such as highly skilled migrant graduates from India felt about participating in the development of their country after exposure in overseas environments. Their inclination to show commitment to a state in which they felt prejudiced during White minority rule and the belief that would still be prejudiced in the current era of African majority rule, was virtually nil. Siddiqui and Tejada (2014) found in their survey of 778 migrants in four countries in Europe that $62 \%$ felt that they could make a positive impact on India's development (see also Singh, 2003; Kapur, 2004; Mani, 2009). Those South African medical personnel who have migrated and who want to migrate did not see themselves as returnees who wanted to act as agents of change and development. Their return to South Africa would be only as short-term visitors.

Against the plethora of problems that were spoken about, it was the issues of education and employment for the younger generation that appeared to have mattered most. The widespread allegations of the deterioration in educational institutions had become a matter of serious concern for middle and upper class parents, and the allegations of electoral fraud had become a matter of serious concern. The purported fraud in the 2011 local elections in Reservoir Hills had, in terms of the tone of the conversation, brought home a reality about future elections in South Africa that was going to reduce democracy to a mere word. One of the guests had acceptably described voting patterns in South Africa in a phrase that they showed no disagreement among the group. After describing how President Zuma allegedly "[...] bulldozed his way into being accepted as the President at the ANC's Polokwane Conference in December 2007 by all the provinces, after seven of nine provinces first rejected him, and the rigged results of the Reservoir Hills local elections", her belief was that the "Africa syndrome has finally arrived in South Africa [...]. The people of this country should no longer expect fair play in any move forward. Privileges and richness will now only be for those who hold the reins of power".

There was fair expectation among the residents of Reservoir Hills for victory of their popular candidate in the local elections. His reputation was built up through his visibility and commitment to a clean and safe environment. However, one of his supports bemoaned his status:

Africans from the squatter camps and a few ANC inclined Indians from the area believe he was basically racist because his leadership of the local Community Watch Policing Forum were on the lookout for young African thieves. 
Pro ANC supporters were alleging that keeping the area crime-free was akin to a form of ethnic cleansing of Africans from the area. But the local residents often tend to retort that affirmative action as well is a form of ethnic cleansing when their children are denied places in Universities to study medicine, commerce or engineering, or when employment opportunities preclude Indian youth from consideration through the application of affirmative action policies (Singh and Khan, 2013). Since the year 2000, when the Employment Equity Act 1998 was being implemented more rigorously to bring about a proportional distribution of employees in work places, the all-inclusive concept "Black", which included Africans, Coloureds and Indians, was being interpreted to mean African first, then other previously disadvantaged groups such as Coloureds and Indians. In other situations the word was and is more so of late, being interpreted to mean African woman first and then African male, inhibiting chances of others from being considered at all. ${ }^{9}$

In retrospect, the end of the evening's socialisation made sense of Keesing's (1981) notion of social groups revealing "connected identity relationships". While the evening was an awaited get-together for long lost friends, the intensity of parts of the conversations were intended to throw up feelings about change in post-apartheid South Africa. Much of it was negative and had brought out the situation of change taking place as though it was designed to make people of Indian origin feel and look different from Africans. The issue of minorities in a multi-racial polity and the hierarchal relationships that emerge from them as a result of majoritarian tendencies to dominate were intrinsic to the conversations. Disenfranchised South Africans fought a long and difficult battle against apartheid as one group viz. as "Blacks" - incorporating Africans, Coloureds and Indians. But soon after the achievement of dismantling apartheid and voting in the most popular party in April 1994, the African National Congress, Coloureds and Indians were no longer as "Black" as they used to be when a collective sustained launch against White minority governance prevailed. The current mood in South Africa is aptly captured in Hobsbaum's (1996: 355) ominous observation: "The characteristic nationalist movements of the late twentieth century are essentially negative, or rather divisive. Hence the insistence on 'ethnicity' and linguistic differences, each or both sometimes combined with religion."

At the beginning of every year since 2000 the author is one among many Indian academics who are approached by students and parents to help register their children in either medicine, engineering or commerce, because they are increasingly being marginalised for admission to these faculties. 


\section{Responses from overseas doctors}

The responses from the three doctors were interesting as well challenging to the parents who felt they had serious choices to make about their children's future in education, employment and quality of life. The notion of "quality of life" was rhetorical and often used to express dismay at the increasing levels of insecurity home owners felt through frequent attacks against so many of them over the last decade and a half. Among middle and upper class families in Durban, there was agreement when one of the doctors raised the point that their high standards of life hardly differed from their counterparts anywhere in the world. The standard of their housing, the motor vehicles that they drove and the travel that they often did amounted to a quality of life that stands favourably to other middle and upper classes in stable countries of the world.

FT was a 64 year-old cardiologist who did his first medical degree between 1967 and 1972 in Durban. He was a father of three sons when he decided to take up an offer in Los Angeles after he "half-heartedly" applied for a post in one of the hospitals there. It was his first class passes at the University of Natal's Medical School (when it was restricted to Indians only during apartheid), his winning an international research award overseas, and his work at the Groote Schuur Hospital in Cape Town where the world's first heart transplant was done by Dr Chris Barnard, that held him in good stead for the job offer in Los Angeles. His departure with his family in 1985 was based on fears of the political situation in South Africa deteriorating when a Black majority rule became a reality. He felt justified, after hearing people preoccupy themselves during their times of leisure, with talk about "[...] who just attacked, how the government ministers are stealing, and how the state of education appears to be on a rapid decline". Now a father of five children, two of whom were born in the USA and two of whom are now also doctors, he felt that his decision was the correct one to have left South Africa. Close to retirement in the USA, he is disinclined to return to South Africa for long periods. Since his children have accepted the American way of life, and since they have also been influenced by the media and friends about allegedly deteriorating conditions in South Africa, his return to South Africa is a moot issue. As a doctor, he was appalled by the conditions in two state hospitals that he had visited, because there were no specialists, and was told by younger doctors that some of the most basic requirements for treating patients, such as swabs, needles and functional equipment were not easily available. 
The second doctor, VS, also a cardiac specialist, was a 57 year old who was employed in one of the most respected cardiac units in the world, based in the USA. He, too, completed his first medical degree at the University of Natal, but went on to study further in London in 1980. After graduating with a first class pass and being admitted to the Royal College of Surgeons, he returned to South Africa to resettle and build a private practice. But the deterioration in the nature of the fight against apartheid during the mid1980s caused him to lose faith in the future of South Africa. His opinion about the "necklacing" 10 of apartheid collaborators in the African townships forced him to look into the future with what he called "[...] a visionary mind". He had felt that the tactics that were employed by the popular organisations against the apartheid rulers was going to remain for a long time after a popular African government came to power. This was because "[...] no other African government in the country had shown the ability to build upon what colonists had left behind in infrastructural developments. Accepted that colonialism was cruel, but political power in Africa was no less than personal rule, with a 'big man' at the centre and incompetent cronies around him." After hearing accounts of incessant violence in the country by whoever he met, he felt vindicated by making the calculated decision that he made in 1987 when he did leave. VS made a significant contribution to the pattern of heart attacks and the times of day that they may occur among the varying types of people who are likely to fall victim to it. His work is now significant to heart specialists, especially students working towards specialisation. After visiting his alma mater in Durban, he was "[...] saddened to see how conditions had deteriorated there [...] the syllabus they are following and the quality of students that they are admitting is dragging the place right down $[\ldots]^{\prime \prime}$. VS felt that unless greater care is taken to revive the medical school "[...] by a proper leadership that is not obsessed with race-based admissions, the future of a great medical school in this country is going to just fall [...] I can now understand why the American authorities are asking UKZN medical graduates when they graduated and who was their Dean when they did [...] because they no longer want the more recent student graduates from here $[\ldots]^{\prime \prime}$.

The third doctor, KL, now a 61 year-old kidney specialist in Kentucky, USA, also was a University of Natal medical graduate. He left South Africa in 1989, because he felt there was no hope for South Africa: "White racism and African incapacity was a recipe for total disaster. It is going to take the

10 Putting a tyre around one's neck and setting him/her alight. 
Africans generations to make up for the time they lost over the last few centuries. While it is not their fault for being so much behind the other race groups in South Africa, it is up to the leadership to show they can do it for their people. But every time I come to South Africa, I keep hearing how bad the situation is becoming. If hospitals are not being equipped properly, and if there is no political will to control the level of crime in this country, then what is the point of blaming everything on apartheid? This is what I heard one Minister say the other day on TV [...] Whites don't have political control anymore, they [used to] have [...]". KL is now the author of at least 160 academic papers in his subject, and boasts about being the highest annual publisher in his field in the USA. He is presently given special status as a researcher in his institution and is considered a leading authority in human kidney research. The facilities that he has to work with, the funds that he is able to raise for research, the students he supervises at post-graduate level and the general congeniality of his work environment, has made him a permanent resident of the USA. He believed that funding in South Africa would have been reasonably available, but conditions here would not have put him in the cutting edge of research like he has it in the USA. His present task in the USA is to travel around the country delivering lectures and holding workshops, and doing the same in other European countries. But he does so as an American citizen. Like his two friends in the social gathering, he believed that the medical environment in South Africa is not sufficiently encouraging to keep the best minds behind. Issues of concern to civil society in contemporary South Africa, such as the high crime rate and perceptions of government corruption, are unlikely to abate for a long time to come. His opinion was that "[...] those who are worried about making progress in their careers or who are concerned about their children's futures, should leave country, unless they feel strongly about being able to make a difference $[\ldots]^{\prime \prime}$.

A striking feature of all three specialists who were special guests of the evening was that they graduated from the same institution but over different years; they had become world renowned figures in their own right; and their reasons for leaving South Africa for the United States were similar. While they expressed pride in having to leave South Africa because their forecasting of chaos after white minority rule appeared to have proven true, they were equally elated at not having to deal with White racism any longer as well. There was a painful recollection by one of the specialists who chose to remain in South Africa as a private practioner, but who trained at the University of Witwatersrand. He was emphatic in his belief, about how the 
Jewish element there had deliberately suppressed Indian medical students' performances to ensure that White students did not stand second best to them. The University of Natal expressed resonance with their own experiences as well with their White, mainly English origin lecturers. While passing their exams was not a problem, the grades that they received, as they perceived it, were almost always lower than what they felt they should have received. They took solace in the fact that going to the USA had allowed them opportunities that they believed would not have been as attractive in South Africa. The encouragement that they have received there allowed their full potential to manifest and to become far more internationally renowned than they otherwise would have been.

Not being able to perform to their maximum is equally a gripe among newly graduated medical students as well. The issues that they have raised are presented not only as hurdles to their upward aspirations in medicine, but also as push factors either away from medicine if they remain in the country (SA), or to leave the country for better prospects overseas (Singh and Khan, 2013).

\section{Responses from newly graduated doctors}

The chances of being admitted to study medicine in South African universities if you are Indian, has become a major issue for those from this race group who want to become doctors. Equity policies are applied in terms of regional demographics, so that African students have a chance at becoming doctors and boosting the generally low pool of African doctors in the country. While such a decision is rooted in the racially discriminatory policies of the apartheid past, it has become a source major of discontent among people of Indian origin. Admission criteria for medical school in what was once an all Indian institution attached to the University of Natal (now University of KwaZulu-Natal) differs by up to $25 \%$ in favour of the African applicant. While the Indian applicant is only considered with an $85 \%$ pass mark in the $12^{\text {th }}$ grade of school, the African applicant can be admitted with a mark of $65 \%$. But many Indian applicants have marks exceeding $90 \%$, making it increasingly difficult for those with $85 \%$ to gain entry. ${ }^{11}$

11 In the year 2000 the author transported his niece for an interview at UKZN's Medical School. Standing before her was a young African male who stated that he was called for an interview even though he had a 55\% mark in grade 12. After his interview he stated that he was accepted but that he was not sure if that's what he wanted to do. Academics in the Medical School continue to bemoan the fact that they have to teach students who are not adequately prepared for Medical School. While they often refer to African students because English is their second language, Indian students are a problem in this situation 
While theoretically the minimum entrance mark is $65 \%$, it is particularly difficult for Whites, Coloureds or Indians because of demographic norms. Since Indians are the smallest among the three minorities $(2.5 \%$ of South Africa's total population), competition for their placement is enhanced phenomenally. Once they graduate, another set of problems appear to bedevil the aspirant doctor in hospitals. Poor hospital management, dysfunctional machinery or its non-availability to carry out tests, lack of basic treatment utensils and materials, lack of hot water and blankets, as well as being overworked, have become characteristic problems in state run hospitals. These issues have become a major hindrance to their duties and hopes of working in a congenial environment that is supportive of doctors' aspirations to further their studies in medicine. Young graduates' complaints about not being able to function because of these reasons were reinforced by a front page headline article in Durban's extensively read evening newspaper, the Daily News. The South African Medical Association Chairman's veiled attack against the ruling ANC government's reputation for alleged nepotism and lack of understanding of real issues affecting healthcare, would help to capture and reassert the ever recurring complaints of the young medical graduate respondents:

Cadre deployment was a driving force behind the exodus of young doctors from the public health sector [...]. It was only politicians who believed that doctors were leaving because of poor pay [...] you have someone with no medical background or experience running a medical institution, which in itself lacks adequate necessary equipment - or where the machinery is available, it is found to be dysfunctional. These young doctors are fresh from university and they need mentors. They get frustrated when they are unable to attend to patients, some in critical condition [...]. We train between 1350 and 1500 students per year, and that's not enough because the demand is huge. We need to train about 15,000 to 20,000 students (across all medical disciplines) a year to meet the demand. We therefore need to establish more medical schools in our own country. We need a serious dialogue on what needs to be done to improve and provide quality healthcare services. (Daily News, 27 August 2014)

Two other responses from elders of two young girls who went to study in Romania and returned after completion of their studies, demonstrated another dimension to the problems that young medical graduates face in South Africa. ${ }^{12}$ Despite the Romanian medical degree enjoying recognition

because they are among the highest achievers in their last year of school (grade 12).

12 Casual conversations turned interviews with a father and an uncle bemoaning the difficulties that their younger family members experienced with the national Department 
as a European Union qualification, the Department of Health has a policy that requires them to write another examination, set by the Health Professional Council of South Africa, before acceptance into the local medical fraternity. But the allegation is that the examination is set up to constrain if not fail the students, because most are of them are Indian, and many of them have also set off to study abroad in countries such as Mauritius and India which allegedly is a source of annoyance to the South African nation state.

One of the elders of the Romanian graduate, a father, said that if his daughter did not get through the examination, she would go to work somewhere in Europe, where the possibilities were good for her. His frustration showed in his voice when he stated: "She is my youngest child and I will miss her. But you know what? She will be safer in Europe and away from all these threats of HIV needle pin pricks, and the violence and rubbish in this country. I am fed up - I had to put most of my savings for my retirement into her education overseas, because she could not get a place here. So I will let her go if she wants to." The second was an uncle who spoke of his brother's daughter having just returned from Romania. His was a voice of concern and helplessness: "My brother just lost his son in an accident, just after becoming a father. He wants his daughter home because he cannot bear the loss of his son and his daughter being so far away from home. This government is just not playing fair with our children." The responses from both the father and uncle in these instances demonstrate several dilemmas among Indians' career building prospects in South Africa. Both young girls went to Romania to study because they were denied places in South Africa's medical schools; while both could practice in Europe with their qualifications, the examinations that they faced in South Africa were deemed unfair. A major complaint about the examination was that they were not exposed to past year examinations, not told why or how they failed and were not given any specialised classes to facilitate their preparations for the examinations. The situation was understood in racial terms - that the state is aware that the graduates returning from Romania are Indian, and it was the state's intention to make it as difficult as possible for them to practice in South Africa. Against such odds families in these situations believe that their predicaments are forms of subtle racism.

of Health in accepting a European Union approved medical degree. The interviews were unintended but helpful to research for this paper. 


\section{CONCLUSION}

While the foregoing discussion centred largely around a single evening and captured the views from the Indian population, it bears a striking resonance with Hobsbawm's (1996) observation about the divisive nature of nationalist movements of other countries, too, in the late twentieth century. It is clear that among Indian medical graduates the inclination to migrate was and still is about escaping perceived and new realities surrounding the socio-political conditions in South Africa. In the apartheid era, the strategy for domination was to legislatively separate people by race and ethnic affiliation. This was a crude form of racism that unashamedly privileged Whites over all other classified groups with one intention in mind, i.e. to maintain their hegemonic position over the majority population as rulers and key service providers, and to ensure that most Africans remained in the rural areas.

The consequences were inevitable in that there developed a significant disproportion of African medical personnel to service their own communities, let alone the right to work where they preferred to. When viewed against the wider patterns of marginalisation and isolation, African anger and commitment to redress the imbalances of the past, it is not surprising. Neither is it that minority groups such as people of Indian origin and privileged Whites are beginning to resist new forms of domination by the state. Under the rubric of "equity" and "fair discrimination" the post-apartheid state is trying to encourage more African school leavers in the $12^{\text {th }}$ grade to enter into medicine and other prestigious fields such as engineering and commerce. This approach is in essence a strategy of domination in as much as it might be a genuine attempt to redress the inequities of the past. Domination, in the broader sense of the word, by the African majority can be best achieved through investment in human capital that will break the vestiges of past reliance upon White, Indian and Coloured professionals, including medicine. But the problems are exacerbated by the persistent claims of mismanagement of educational and medical facilities, generally poorer performances by African leaners before and after they enter tertiary institutions, decrepit state run educational institutions, long working hours, unattractive physical conditions in the rural areas, a lack of incentives for new medical graduates to opt to serve in these areas, and the overall factor of violent crime throughout the country. When the state invests significantly less than expected annually in the production of medical personnel for the country's needs, the situation then must also call into question the state's use 
or misuse of its power in social service delivery. The situation is worsened, according to Indian residents, when electoral exercises such as voting for municipal representatives in residential areas are hijacked by non-tax paying squatters, such as in Reservoir Hills. Apart from being given an equal chance to vote as the taxpaying residents, squatters bussed in more people, mainly African students staying in University residences, even though they were not registered to vote in the area. The criterion was suddenly changed to the production of a South African document. Medical doctors (people of Indian origin) left South Africa because of calculated forecasts of violent outbreaks after the dismantling of apartheid. While it did not happen in the political sense of a civil war between Whites and Africans, violence in the country is widespread and endemic. And although promises by the ANC to open all doors of learning to the masses prevailed throughout the struggle against apartheid, the takeover of political power through the ballot box was vitiated by its extensive mismanagement of medical facilities throughout the country. Such accusations are equally accompanied by the alleged lack of political will to tackle crime more effectively. While the three guests from the USA reinforced these widely held beliefs about social conditions in South Africa, they, however, also escaped what they experienced as "White racism". Their relocation to the USA was induced by the propensity of harsh racial conditions to foster violent opposition, to which they now claim vindication for their decisions to migrate. Younger medical graduates continue to express similar feelings about their personal and family safety, and about poor working conditions, as Van der Vyver and de Villiers' (2000) research in Saskatchewan had shown. The limited places in medical schools throughout the country and the lack of preparedness of the state to meet the needs of medical care in the country through institutional incapacity, has now turned into beliefs and accusations of "reverse discrimination" against the state, especially by people of Indian origin.

Foucault is known for describing the concept of power as a series of force relations which are free-flowing. But it can be unpredictable and easily reversed to translate into relations of resistance. He described "domination" as a process of free-flowing power relations which can become an inhibitive force if it crystallises into a more rigid hierarchical structure. If this conception of Foucault's notions of power and domination are disaggregated when applied to the 2011 electoral process in Reservoir Hills, it becomes relatively easy to understand, especially when viewed against a free and fair electoral process which was allegedly hijacked and manipulated. Flight from the country becomes a non-violent form of resistance to deteriorating 
perceptions of political mismanagement. The resistance in the Foucauldian sense of the word is to find places to study in other countries of the world, complemented by social discourses that serve as comfort against a state that appears to be losing legitimacy in the eyes of minorities, however insignificant this may be against an African majority that still supports it.

While people of Indian origin are a mere $2.5 \%$ minority segment of South Africa's population, their visibility through their middle and upper class positions are difficult to ignore. There is a mutual responsibility on the part of both the state and Indians in areas such as Reservoir Hills, to work towards an educational programme that addresses each segment's misgivings about the current pace and nature of transformation. While squatters are a virtual permanent feature of the urban landscape, the state has a duty to provide them with better quality housing, a crime free environment and ways to represent their interests as taxpaying residents. Anything short of this will continue to contribute towards the atmosphere of mistrust between both communities. While the Indian voters' responses were derogatory against the ANC and IEC for allowing a perceived sense of corruption in the course of the voting, the African squatters ululated upon the victory of their candidate. Herein lay the limitations of this study - in that the views of the African squatters needs to be researched in order to acquire an authentic sense of their needs and wishes. With respect to Indian parents and budding graduates, their wishes are to be given greater opportunities to be accepted in centres such as medical colleges because they are citizens of the country. But the state's programme to address inequities of the past is an even bigger responsibility. The answer may, however, be delivered to anxiety ridden parents if the state acts upon the recommendation about producing the near 20,000 graduates that they ought to than the barely 1200 per annum. Investment in more medical schools and better incentives for working in the rural areas can only mean more doctors for the future, which in turn means having more care-givers contributing towards the establishment of a healthier population. New policies ought to move towards building greater inter-racial trust, more infrastructural developments that houses people and provides them with sustained employment, and improving the image of the South African Police Services. These issues are crucial to unpacking the challenges that confront contemporary politics in South Africa and it leaves much room for future research and policy directions. 


\section{REFERENCES}

Arnold, P. C. (2011). A Unique Migration: South African Doctors Fleeing to Australia. Seattle: Create Space.

Bezuidenhout, M. M., Joubert, G., Hiemstra, L. A. and Struwig, M. C. (2009). Reasons for doctor migration from South Africa, South African Family Practice, 51 (3): 211-215, doi: 10.1080/20786204.2009.10873850.

Carnie, T. (2014). Pollution threat to Durban's tap water, IOL scitech, 27 August 2014, http://www.iol.co.za/scitech/science/environment/pollution-threat-to-durban-s-tapwater-1.1741922\#.VFuPyDTF8zY (01 September 2014).

Diamond, I. and Quinby, L. (eds) (1988). Feminism and Foucault: Reflections on Resistance. Boston: Northeastern University Press.

Foucault: power is everywhere. Powercube - Understanding power for social change, http://www.powercube.net/other-forms-of-power/foucault-power-is-everywhere (16 September 2014).

Gaventa, J. (2003) Power after Lukes: a review of the literature. Brighton: Institute of Development Studies.

Hagopian, A., Thompson, M. J., Fordyce, M., Johnson, K. E., and Hart, G. (2004). The migration of physicians from sub-Saharan Africa to the United States of America: measures of the African brain drain, Human Resources for Health, 2 (17), doi: 10.1186/1478-4491-2-17.

Hartigh, W. den (2012). South Africa, Cuba to train more doctors, Media Club South Africa, 13 January 2012, http://mediaclubsouthafrica.com/democracy/69-youth-andeducation/youth-and-education/2730-cuba (01 September 2014).

Hobsbawm, E. (1996). Ethnic Nationalism in the Late Twentieth Century, in: J. Hutchinson and A. D. Smith (eds). Ethnicity. Oxford: Oxford University Press, 355-358.

Hyslop, J. (2005). Political Corruption in South Africa: before and after Apartheid, Journal of Southern African Studies, 31 (4): 773-789, doi: 10.1080/03057070500370555.

The International Mobility of Health Professionals: an Evaluation and Analysis based on the Case of South Africa, in: Trends in International Migration 2003 (2004). Paris: OECD, 115-151, doi: 10.1787/migr_outlook-2003-4-en.

Kalombo, G. (2005). Understanding Political Corruption in Post-Apartheid South Africa: the Gauteng Experience: 1994-2005 (doctoral dissertation). Johannesburg: Faculty of Humanities, University of Witwatersrand.

Kapur, D. (2004). The causes and consequences of India's I.T. boom, India Review, 1 (2): 91-110, doi: 10.1080/14736480208404628.

Keesing, R. M. (1981). Cultural Anthropology: a Contemporary Perspective. New York: Holt, Rinehart and Winston.

Mani, S. (2009). High Skilled Migration from India, an Analysis of its Economic Implications. Thiruvananthapuram: Centre for Development Studies (Working Paper, no. 416), http://opendocs.ids.ac.uk/opendocs/bitstream/handle/123456789/3134/wp416. pdf? sequence=1 (26 August 2014).

Ndaliso, C. (2014). Doctors Blame Cadres, Daily News, 26 August 2014, http://www.iol. co.za/dailynews/news/doctors-blame-cadres-1.1741059\#.VFuFPzTF8zY (01 September 2014). 
Pillay, S. (2011). Who did the Indians vote for?, The Witness, 09 June 2011, http://www. witness.co.za/index.php?showcontent\&global[_id]=62374 (26 August 2014).

Robinson, M. (2014). SA needs rural doctors, Mail $\mathcal{E}$ Guardian, 08 April 2014, http:// mg.co.za/article/2014-04-08-comment-sa-needs-rural-doctors/ (01 September 2014).

Rondganger, L. and Ndaliso, C. (2014). SA loses R8.5bn to car theft, Daily News, 27 August 2014, http://www.iol.co.za/dailynews/news/sa-loses-r8-5bn-to-car-theft-1.1741669\#. VFuGSjTF8zY (01 September 2014).

Siddiqui, Z. and Tejada, G. (2014). Development and Highly Skilled Migrants: Perspectives from Indian Diaspora and Returnees, International Development Policy / Revue internationale de politique de développement (Online), 5.2, doi: 10.4000/ poldev.1720.

Singh, A. and Khan, S. (2013). Against the tide of "justifiable discrimination": reengineering identity and options among minority (Indian) medical graduates in South Africa, Diaspora Studies, 6 (1): 1-12, doi: 10.1080/09739572.2013.843288.

Singh, S. (2003). Economic Impact of Return Migration of Highly Skilled I.T. Professionals from the United States to India (thesis draft, 13 March 2003), http://web.mit.edu/nruiz/ www/Documents/Shinu's\%20Thesis\%20Draft.pdf (02 September 2014).

Smith, M. (2009). White exodus - is it hype?, RT, 09 March 2009, http://rt.com/news/ white-exodus-is-it-hype/, (26 August 2014).

Van der Vyver, J. D. and de Villiers, P. J. T. (2000). The Migration of South African Graduates to Canada: a Survey of Medical Practitioners in Saskatchewan, South African Family Practice, 22 (1): 17-22.

Van Rooyen, J. (2000). The New Great Trek: The Story of South Africa's White Exodus. Pretoria: Unisa Press.

Weedon, C. (1987). Feminist Practice and Poststructuralist Theory. London: Blackwell. 


\title{
Društveni diskurs, zone ugode i globalizirajući svijet: južnoafrički indijski liječnici - emigranti i rezidenti - o potrebi migriranja
}

\author{
Anand Singh
}

\section{SAŽETAK}

Rad se temelji na mišljenjima i intervjuima s indijskim medicinskim osobljem koje radi izvan Južnoafričke Republike i u njoj. Istražena su gledišta dviju skupina: liječnika opće prakse i liječnika specijalista. Prva skupina liječnika zaposlena je izvan zemlje i s njima su vođeni individualni i grupni intervjui. Oni pripadaju dobnoj skupini iznad 60 godina, dok je skupina koja živi u zemlji mlađa od 40 godina, a predstavljena je odgovorima njihovih bliskih srodnika s kojima su provedeni individualni intervjui. Dok starija skupina smatra da ima dvostruku prednost - iskustvo i mudrost, mlađi često izražavaju oprečne osjećaje. S jedne strane zadovoljni su svojim uspostavljenim zonama ugode, ali s druge iznose suprotne stavove kada se uspoređuju s kolegama koji rade u drugim zemljama, osobito na Srednjem istoku i $\mathrm{u}$ razvijenim zemljama s engleskoga govornog područja (posebice $\mathrm{u}$ »velikih pet«: SAD-u, Kanadi, Ujedinjenom Kraljevstvu, Australiji i Novom Zelandu). Bez obzira na to gdje se nalaze i što misle o sebi, razgovori s pripadnicima obiju skupina sadržavali su mnogo protuslovlja, od žalosti i razočaranja do sreće i povjerenja u vlastitu budućnost.

KLJUČNE RIJEČI: migranti stručnjaci, medicinski stručnjaci, Indijci, Južnoafrikanci, globalizacija 